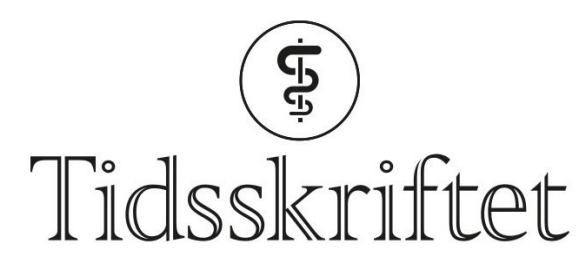

DEN NORSKE LEGEFORENING

\title{
Diabetisk ketoacidose etter immunterapi mot lungekreft
}

\author{
KORT KASUISTIKK

\section{PER KRISTIAN SKORPEN} \\ E-post: perkrskorpen@gmail.com \\ Medisinsk klinikk \\ Nordlandssykehuset Vesterålen \\ Per Kristian Skorpen er spesialist i indremedisin og overlege. \\ Forfatteren har fylt ut ICMJE-skjemaet og oppgir ingen interessekonflikter.

\section{JULIA MARGULL} \\ Medisinsk klinikk \\ Nordlandssykehuset Vesterålen \\ Julia Margull er lege i spesialisering. \\ Forfatteren har fylt ut ICMJE-skjemaet og oppgir ingen interessekonflikter.
}

En mann i 6o-årene ble behandlet med pembrolizumab mot ikke-småcellet lungekreft og utviklet diabetisk ketoacidose. Pembrolizumab er et monoklonalt antistoff godkjent for behandling av flere kreftformer. Diabetes mellitus type 1 er en sjelden bivirkning av immunterapi mot kreft, og vi beskriver her det første tilfellet av diabetisk ketoacidose som følge av slik behandling som er rapportert i Norge.
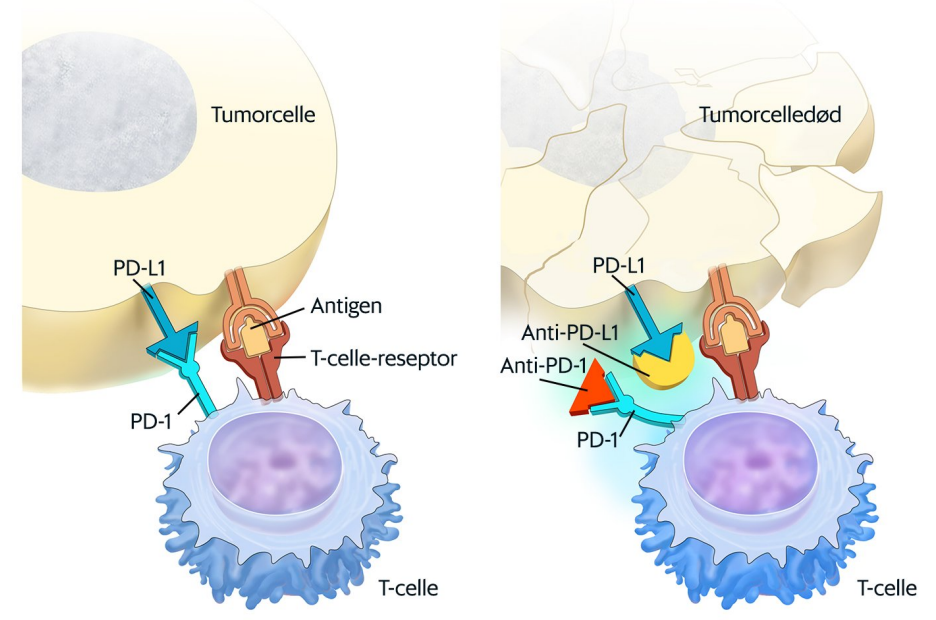

Figur 1 Når PD-L1 (programmert celledød-ligand-1) på tumorcellen binder seg til PD-1-reseptoren (programmert celledød-1-reseptor) på T-cellen, hemmes T-cellens drapsmekanismer og forhindrer immunforsvaret fra å angripe tumorcellen. Blokkering av PD-L1 eller PD-1 gjør at T-cellen kan angripe tumorcellen etter antigenbinding. Gjengitt med tillatelse: @ Terese Winslow LLC, U.S. Govt has 
certain rights.

En mann i 6o-årene ble innlagt på medisinsk avdeling med mistanke om sepsis etter at han ble funnet med endret bevissthet og takypné med respirasjonsfrekvens på 33 pust $/ \mathrm{min}$. Ved ankomst var han uklar og hadde Kussmauls respirasjon med ketonlukt og en blodsukkerkonsentrasjon på 69,7 mmol/l. Blodtrykket var 172/97 mm Hg, pulsfrekvensen 99 slag/min og temperaturen $36,8{ }^{\circ} \mathrm{C}$ målt rektalt. Laboratorieprøvene viste $\mathrm{pH} 7,18$ (referanseområde 7,37-7,45), $\mathrm{pCO}_{2} 2,5 \mathrm{kPa}(4,7-6, \mathrm{o} \mathrm{kPa}$ ), bikarbonat $7 \mathrm{mmol} / \mathrm{l}(22-27 \mathrm{mmol} / \mathrm{l})$, natrium $118 \mathrm{mmol} / \mathrm{l}$ (136-146 mmol/l), kalium 8,2 mmol/l (3,5-5,0 mmol/l), kreatinin $141 \mu \mathrm{mol} / \mathrm{l}$ (6o-105 $\mu \mathrm{mol} / \mathrm{l})$, CRP 33 (<5), Hb 12,3 g/dl (13,4-17 g/dl) og leukocytter 17,5 · $1 \mathrm{o}^{9} / \mathrm{l}$ (3,5-11 $\left.\cdot 10^{9} / \mathrm{l}\right)$. Pankreasamylaseverdien var normal ( $45 \mathrm{U} / \mathrm{l}$, referanseområde $\left.10-65 \mathrm{U} / \mathrm{l}\right)$, mens lipaseverdien var forhøyet (749 U/l,<30o.) Urinstiks viste $3^{+}$for ketoner. På bakgrunn av kliniske undersøkelser og supplerende prøver konkluderte vi at mest sannsynlig diagnose var ketoacidose, og ikke sepsis. Blodkulturer ble derfor ikke bestilt.

Pasienten fikk behandling med væske og insulindrypp etter avdelingens prosedyre for behandling av ketoacidose. Blodsukkerkonsentrasjonen sank fint med tilfredsstillende korrigering av acidosen. Etter hvert kunne man gå over til subkutan insulinbehandling. Ved utskrivelsen brukte pasienten 55 E insulin degludec én gang daglig og 15 E insulin aspart til måltidene. Tre måneder etter den aktuelle innleggelsen var pasienten velregulert på én dose insulin degludec daglig og insulin aspart til måltidene.

Prøver som assosieres med type 1-diabetes, f.eks. s-anti-GAD, s-anti-IA2 og s-insulin-antistoff, var alle negative. C-peptid-verdi målt fem uker etter innleggelsen var under $7 \mathrm{pmol} / \mathrm{l}$ (370-1 470 pmol/l). HbA1c\% ved innleggelsen var $8,4 \%$. Thyreoideaprøver var normale.

Det kom frem at pasienten cirka to måneder tidligere var blitt diagnostisert med adenokarsinom i høyre lunge. PET-CT hadde vist tegn til flere metastaser, og lungebiopsi hadde påvist PD-L1-uttrykk i $95 \%$ av cellene. Han hadde ingen kjent diabetes og HbA1c\% var på det tidspunktet 5,7\%. Det hadde blitt startet behandling med pembrolizumab $200 \mathrm{mg}$. Første dose ble gitt cirka en måned før, og andre dose 16 dager før den aktuelle innleggelsen med ketoacidose. Etter strålebehandling for lungetumoren vil man fortsette med pembrolizumab.

\section{Diskusjon}

Pembrolizumab er et humanisert monoklonalt antistoff som bindes til programmert celledød-1-reseptorer (PD-1-reseptorer) og blokkerer interaksjonen med ligandene PD-L1 og PD-L2. PD-1-reseptoren er en negativ regulator av T-celle-aktivitet. Medikamentet er blant annet indisert hos pasienter med ikke-småcellet lungekreft som uttrykker PD-L1 med over $50 \%$ «tumor proportion score».

Immunrelaterte bivirkninger forekommer relativt ofte hos pasienter som behandles med monoklonale antistoff. Alvorlige bivirkninger er rapportert hos inntil $10 \%$ av pasientene (1). De fleste tilstandene -eksempelvis immunrelatert pneumonitt, kolitt, hepatitt og nefritt behandles med kortikosteroider. Diabetes mellitus type 1 er en sjelden bivirkning, og steroidbehandling har ikke vist seg å være effektivt i de få tilfellene hvor det er rapportert forsøkt (2-4).

Lipasestigningen hos vår pasient ble oppfattet som uspesifikk, og han oppfylte ikke kriteriene for pankreatittdiagnose. Det er anbefalt å ikke måle amylase og lipase hos pasienter behandlet med immunterapi der det ikke er klinisk mistanke om pankreatitt (5).

I en gjennomgang av alle publiserte tilfeller av diabetes etter PD-1-reseptor-behandling fant man 42 tilfeller, hvorav 12 hadde fått behandling med pembrolizumab, og 30 ble innlagt med ketoacidose (2).

Vår pasient hadde ikke fått cytostatika eller annen behandling enn pembrolizumab etter at kreftsykdommen ble diagnostisert. Han hadde normal HbA1c\% ti uker før innleggelsen med ketoacidose, og vi har konkludert med at utviklingen av diabetes mellitus er sikkert relatert 
til behandlingen med antistoff.

Steroidbehandling har forgjeves vært forsøkt for å redde betacellefunksjonen hos pasienter med immunterapiutløst diabetes, og man konkluderte i en kasuistikk med at behandlingen var uten effekt på den immunrelaterte reaksjonen (3). Det er også forsøkt steroider kombinert med glukagonlignende peptid-1-analog (GLP-1-analog) uten at man har klart å redde betacellefunksjonen (4). Den japanske diabetesorganisasjonen uttalte i 2016 at steroidbehandling ikke anbefales i behandlingen av diabetes sekundært til terapi med PD-1antistoff (4).

De fleste rapporterte tilfellene av diabetes mellitus type 1 etter behandling med PD-1antistoff er enkeltkasuistikker. Mange beskriver dramatiske forløp med ketoacidose slik som hos vår pasient. Ketoacidose er en livstruende tilstand, og pasienter som behandles med PD-1-antistoff, må få god informasjon om diabetessymptomer, slik at eventuell behandling kan startes så tidlig som mulig.

Enkelte har valgt å fortsette behandlingen med monoklonalt antistoff etter at blodsukkeret er normalisert med insulin $(4,6)$, mens andre har valgt å avslutte den (7). Vår pasient er satt opp til videre behandling med pembrolizumab.

\section{Konklusjon}

Immunterapi ved kreftsykdom har andre bivirkninger enn behandling med cellegift. Leger som behandler pasienter med immunterapi, må være observante på immunrelaterte endokrinopatier. Disse vil oftest kreve varig behandling med hormonsubstitusjon. Alvorlige komplikasjoner som diabetisk ketoacidose forekommer, og pasientene må informeres om et bredt spekter av mulige bivirkninger.

\section{LITTERATUR:}

1. Champiat S, Lambotte $O$, Barreau E et al. Management of immune checkpoint blockade dysimmune toxicities: a collaborative position paper. Ann Oncol 2016; 27: 559-74. [PubMed][CrossRef]

2. Clotman K, Janssens K, Specenier P et al. Programmed cell death-1 inhibitor-induced diabetes mellitus. J Clin Endocrinol Metab 2018; 103:3144-54. [PubMed][CrossRef]

3. Aleksova J, Lau PK, Soldatos G et al. Glucocorticoids did not reverse type 1 diabetes mellitus secondary to pembrolizumab in a patient with metastatic melanoma. BMJ Case Rep 2016; 2016: bcr2016217454. [PubMed][CrossRef]

4. Fukui A, Sugiyama K, Yamada T. A case of Nivolumab-induced fulminant type 1 diabetes with steroids and glucanon like peptide 1 administration during early onset. J Clin Case Rep 2016; 6: 883. [CrossRef]

5. Friedman CF, Clark V, Raikhel AV et al. Thinking critically about classifying adverse events: inscidence of pancreatitis in patients treated with ninolumab + ipilimumab. J Natl Cancer Inst 2016; 109: djw26o. [PubMed][CrossRef]

6. Okamoto M, Okamoto M, Gotoh K et al. Fulminant type 1 diabetes mellitus with anti-programmed cell death-1 therapy. J Diabetes Investig 2016; 7: 915-8. [PubMed][CrossRef]

7. Hariz M. Diabetes ketoacidosis after treatment with pembrolizumab. J Clin Transl Endocrinol 2017; $5: 4-5$.

Publisert: 25. februar 2019. Tidsskr Nor Legeforen. DOI: 10.4045/tidsskr.18.0597

Mottatt 27.7.2018, første revisjon innsendt 12.9.2018, godkjent 20.11.2018.

(C) Tidsskrift for Den norske legeforening 2020. Lastet ned fra tidsskriftet.no 